\title{
XVI. Some account of the caves near Baug, called the Panch Pandoo
}

\section{Captain F. Dangerfield}

To cite this article: Captain F. Dangerfield (1820) XVI. Some account of the caves near Baug, called the Panch Pandoo, Philosophical Magazine Series 1, 56:268, 108-115, DOI: 10.1080/14786442008652375

To link to this article: http://dx.doi.org/10.1080/14786442008652375

里 Published online: 23 Jul 2009.

Submit your article to this journal

Џ Article views: 2

Q View related articles $\asymp$ 


\section{[ 108$]$}

XVI. Some Acrount of the Caves near Baug, called the Panch Pandoo. By Captain F. Dangerfield, of the Bomtiay Military Estallishment*

B BEFone entering on a description of these caves, a slight sketch of the wild, mountainots, woody tract of country in which they are situated may perhaps be desirable.

This mountinous tract is contained between the twenty-second and twenty-third degrees of north latitude, ranging for a consi derable extent in the direction of the course of the Nurbuddab, leaving however generally an intermediate plain, about ten or twelve miles broad, between it and the banks of that river. In this range few towns or villages are to be found, it being for the most part peopled by Bheels of the wildest description, few having any fixed habitations.

In the midst of this range, in north latitude $22^{\circ} 22^{\prime} 15^{\prime \prime}$, and in rearly $75^{\circ}$ east longitude, is the small town of Baug, three miles, and a quarter S. S. E. of which the caves are found.

The town is situated at the foot of a low range of hills about one bundred feet high, which forms the western boundary of a pleasant valley extending north and south about three miles, by an average breadth of one mile. It contains, within a small area surrounded by a low mud wall, about four hundred houses. At the sunmit and extremity of the range near which it is placed, overlooking the town, is a rudely built stone fort now falling fast to decay. The ascent to it is by a small footpath very steep.

Baug is on the road leading from Guzerat to Malwa, by what is termed the Oudipoor Pass. From this place the two roads leading into the latter province diverge; one constituting the Tanda Gaut to the eastward, the other the Tirrella Gaut, leading to Indore, Oujein, or by Rajghur to the northward: this last is by far the hest carriage road.

Previous to these last twenty years of anarchy and desolation Baug is said to have contained between two and three thousand houses, and to have covered a considerable portion of the plain in which it is situated; but, with the exception of two or three pagodas, few vestiges now remain to point out its former extent.

As a town, however, Baug does not claim any antiquity, it having risen into importance about a bundred years ago, from becoming the occasional residence of Jassoo Baumeah, a celebrated freebooter, who possessed himself of the Kotra district, and who built as places of security for his followers and plunder the forts of Soosaree, Baug; and Kooksee.

* From Transactions of the Literary Society of Bombay, vol. ii. 
Jassoo Baumeah beconing by his bold depredations, which extended not only into Malwa but even to the Deckan and Guzerat, so formidable as to excite the serious attention of the Mahratta princes, he was besieged by a large army during forty days in the fort of Kooksee; at the end of which period, finding the place no longer tenable, he made his escape to Baug. To this last place he was pursued, and again besieged; but not being able there to make any stand, he retired to the monntains, from which period nothing further of him is known. His country was divided among the conquerors; Baug, with its dependent villages, falling to the share of Scindiah, to whom it still belongs.

The jungle for some distance round Baug is very open, and the hills do not rise to any considerable height, seldom exceeding one hundred and fifty or two hugdred feet. They appear for the most part to be composed of the floetz and transition rocks, chiefly trap and fint slate; and both these and the valleys abound with iron ore, the brown ironstone, and clay ironstone.

There are at this place some iron works on a small scale, consisting of three smelting furnaces and three forges; giving employment to twenty-four blacksmiths, and many men, women and children, in transporting, pounding, and sifting the ore, which produces about fifty or sisty per cent. of iron of an indifferent quality, chiefly arising from the imperfect fusion and forging of the metal. It is at once wrought into ploughshares weighing about two pounds each. From the little demand, however, the ore is only wrought about three or four months in the year. Each forge pays forty rupees to Government.

The whole of the alluvial soil, which on the lills seldom exceeds six feet in depth, is for ten or twelve miles round Bang strongly coloured with oxide of iron.

On leaving Baug to visit the caves, you proceed for three miles along the high road to Kooksee, when turning to the left, a small footpath, after a quarter of a mile, leads you across the Wangrey river to the hills in which these caves are cut, and which rise close to the left bank of that river.

This range of hills does not exceed in height one lundred and fifty feet, having a direction nearly N.N.E. and S.S.W., the entrance to the caves facing the westward. The lower half of the hill is sloping, but steep; the upper perpendicular. The hill in which these caves are excavated is composed entirely of horizontal strata of sandstone and claystone alternating with each other.

The sandstone, which has an argillaceous cement, is coloured with oxide of iron varying from the deep red to perfect white. With its colour vary also its hardness and the fineness of its grain, the dark red being fine-grained and tolerably hard, the 
white coarse-grained, and so soft as to be rubbed to pieces be tween the fingers, and containing many organic impressions. Different shades of the red sandstone occupy the upper or perpendicular part of the hill, with thin layers of the claystone interposed. A broad stratum, however, of the claystone runs about six feet ahove the top of the caves; and it may here be observed, that it is solely from this stratum that the rock.has given way beneath, causing the destruction of those caves hereafter mentioned.

The caves occupy the centre of the hill, commencing at its perpendicular part. It is through the lower half of the caves, for about six feet from their floor, that the stratum of white sandstone runs; this however reposes on the old red sandstone. The upper part of the eaves. is mostly formed of the light red sandstone.

-The caves are four in number; one only of which, the most northern one, can however be said to be in a state of preservation.

Immediately after crossing the river you ascend up the sloping part of the hill, to the first or most northern cave, by a flight of seventy rudely formed stone steps, and arrive at a stmall landingplace, for the most part overhung by the hill. This bears the marks of having once been formed into a regular viranda, supported by columns, the roof plastered and ornamented, as shown by its fallen fragments. The front of the cave still retains this plaster. At each end of this viranda is a small room containing small ill-covered figures, evidently of modern workmanship, that on the left being a female one much mutilated, that on the right a bad representation of Ganesa.

You enter this cave at the centre, by an unornamented rectangular doorway five feet and a half wide. There is also a similar one to the right, but much choked with the fallen fragments of the roof. The cave derives its sole light from those two entrances; consequently, to examine its remoter parts, the aid of torches is necessary; and as tigers, which abound in this country, have been found in the interior of the caves, this precaution becomes the more requisite.

On entering the cave you are impressed with its gloomy grandeur : it is not, however, till you have been a few seconds in it that you perceive its great extent. The open area of this cave is a regular square, measúring cighty-four feet each side. Its height is fourteen feet and a half. The roof is supported by four ranges of nassy columns; the two centre ones being round; those on the right and left square at the base, but at the heights of five and eight feet formed into hexagons and dodecagons. The roof, but no other part of this cave, bears the marks of having 
having been once ornamented with paintings in square compartments of about one foot. From the frequent smoke of torches, however, sufficient of the design is not at present apparent to admit of any judgement on its merits.

Passing between the centre range of columns, to the end of the caves, you enter an oblong recess, or viranda, measuring twenty feet by twelve, open in front towards the cave, and supported by two hexagonal columns.

In niches on the remaining three sides of this apartment are carved in bold relief, three figures; the centre is a female figire nine feet and a half high; and those to the right and left are male ones nine feet high. On each side of the doorway of the inner apartment described below, there is also a figure of nearly nine feet.

From this recess, or viranda, you enter in its back part, through a small doorway, an inner apartment measuring twenty feet by seventeen; in the centre of which, cut out of the solid rock, is what the natives term "The Churn," being a regular hexagon of three feet three inches each side, surmounted by a plain dome reaching nearly to the roof, to which is is joined by a small square ornament.

Around the large cave also, on three sides, are small apartments, called the dookans, or shops, each measuring nine feet in depth, with a separate entrance towards the cave. There are seven of these to the right, six to the left, and four at the end of the cave, two on each side of the recess.

Entering the second to the left of these small apartments, you perceive, at about four feet from the ground in the opposite wall, a small oblong excavation of about three feet by two; creeping through which, you euter a small apartuent of about twelve feet square, in the opposite wall of which is a similar excavation leading to a like apartment; and so on successively for five small rooms, gradually ascending the hill, the foor of each inner apartment being on a level with the lower part of the entrance from the outer one.

These secret apartments appear originally either to have led, or to have been intended to lead, to the top of the hill: at present, however, they receive neither light nor air, excepting from the first eutrance.

The cave I have described, which is the largest, though in the best preservation by far of the whole, still bears the marks of rapid decay. The shafts of five columns are wanting; and a kind of terrace has been raised with their ruins. The left hand circular column on entering has alco once shared the sáme fate; but has been rebuilt with rude fragments of the same stone, and atterwiards plastered to resemble the other pillars. This plaster 
has, however, almost entirely given way, leaving the rude construction of the column apparent.

Leaving this first cave, and proceeding southward twenty or thirty paces by a narrow ledge round a projecting part of the hill, you enter a second cave, evidently never completed, the columns being left in a rude state with deep marks of the chisel still remaining. This cave is nearly the same in length as the first, by about half the depth. It has originally been open in front, but with the exception of a small part it is now choked up with large fragunents of the hill from above. It contains little worthy of notice.

Leaving the second cave, and returning by the same road, you descend the stone stairs, and proceed along the bottom of the hill southward for about a hundred yards, and then reascend by a rugged steep footpath to the third cave.

This save, which measures eiglty feet by sixty, has been nearly similar in its arrangement to the first; but it is now in a ruinous state from the giving way of a great part of the roof, bearing down in its fall several beautiful columns. This cave, which has none of the gloominess of the first, has been once finished and decorated in a very superior style, and it is apparently the nost ancient of the whole. It has some similar features with the other. In the inner apartment is the octagon, called The Churn, mentioned in the first; but it wants the recess, or viranda, with the sculptures.

The whole of the walls, roof, and columns of this cave have been covered with a fine stuceo, and ornamented with paintings in distemper of considerable taste and elegance. Few colours thave been used, the greatest part being merely in chiaro scuro; the figures alone, and the Etruscan border (for such it may be termed), being coloured with Indian red.

On many places of the lower parts of the wall and columns have been painted male and female figures of a red or copper colour; the upper parts of the whole of which have, however, been intentionally erased. Such of the lower parts (the legs and feet) as remain, show them to have been executed in a style of painting far surpassing any thing in the art which the natives of India now possess.

Leaving this cave by the right hand doorway, and proceeding a few paces further along the hill, you enter a fourth cave nearly similar in dimensions and arrangement to the second, It has however been finished, and is falling fast to decay.

There appears at the extremity of this cave the rude commencement, or perhaps the ruins, of a fifth. It is not however sufficiently accessible, on account of the large frugments of fallen rock, to admit of any correct judgement of its former state. 
The above is a slight description of these caves from a short visit to them during a day's residence at Baug.

In the total absence of books, or referenees of any description, it would be temerity in me to indulge in any speculations, or advance any opinion respecting the figures or other parts of these caves. This part of the subject I must therefore leave to the slight sketches which my time enabled me to make.

Concerning the origin or use of these caves the natives have no tradition. They derive their name from the same fabulous tradition as all remains of Hindu antiquity. They were excavated by the "Panch Pandoos," those celebrated heroes of Indian mythology to whom all wonders are referred.

In concluding I may remark, that the jungle covering this mountainous tract presents (at least at this season of the year) nothing novel for the gratification of the botanist. The northern and the thickest parts consist for the most part of the teak (Tectona grandis Thunb.) and blackwood trees (Dalbergia latifolia Roxb.) with the Feronia elephantum and Erythrina Indica Linn. The more open parts consist chiefly of the Butea frondosa; the babool (Acacia Arabica Linn.), the gum tree (Cordia obligua Wild.), the bayr tree (Zizyphus Jujula Konig), and Morinda umbellata; the digging the roots of the latter plant, for the use of the dyers, giving employment to many of the poorer class in the villages skirting the jungle.

Both this last and the Morinda citrifolia are cultivated also in many parts of this country. In one place there were several of the pudding pipe trees (Cassia Fistula Linn.); but as they were near the site of a ruined village, these were most probably not natives of this jungle.

Camp at Mhow, May 1818.

\section{NOTE BY MR. ERSKINE.}

Captain Dangerfield having politely permitted me to add any observations to his paper which the subject suggests, I shall be exeused for observing that it exhibits a very complete account of a Bouddhist temple, and of the first excavation of that class that has been described in the country in which it is situated. It adds another to the examples of Bouddhist excavations found in India, in countries where we have no historical record that the religion of Bouddh ever existed, and where not a single individual of the sect is now to be found. That the excavations are Bouddhist there seems to be no reason to doubt. The figure and attitude of the contemplative Bouddh are not to be mistaken-; the Churna, or. as it is sometimes called, the Daghop, in this as in other Bouddhist temples, is the principal object of veneration;

Vol. 56. No. 268. Aug. 1820. 
it is generally conical, and is considered as a tomb, or mausoleum, containing the remains or any of the reliques, sometimes only a few hairs, of a Bouddh or Bouddhist saint, to whom the temple is dedicated.-Another circumstance which marks the origin and design of the excavations is the number and arrangement of the small apartments round the temple, called dookans, or shops: these we might expect to find in such a place: they are the cells of the priests, who are always found living in a monastic state round the chief Bouddhist temples in Siam, Pegu, and wherever the religion exists. The numerous smaller excavations at Kanara have the same object, as well as those at Karli. There is no trace of the Brahminical mythology in' the whole excavation, except the mutilated figure of Gunesh at the entrance, which, as Captain Dangerfield remarks, is evidently of a later date. There are no unnatural or distorted human figures, nor any with many heads or limbs. The largest temple leading up to the principal object of veneration at Kanara and Karli is arched; at Baug it is flat; which might be owing either to choice, or to a necessity arising from the nature of the stone at Baug, which seems to be in some places deficient in strength.

\section{William Erskine.}

Nork.-It has been thought proper to subjoin the following letter from Captain Dangerfield to Sir John Malcolm, as it contains some further interesting particulars respecting remains of antiquity in Malwa, that have never been visited by Europeans.

Kurgoond, April 24, 1819.

Dear General,-I have just returned from Wone, and start to-morrow towards Chiculda, which I expect to reach in five marches. I was obliged to halt two days at Wone, to enable me to make even the slightest sketches of the pagodas, or notices of the inscriptions, of which there are several, few of which aty person I can procure can make any thing of. However, I have copied some of them as well as I could; but they are mostly very much worn out, and appear never to have been cut very deep. From all I can as yet make out, they are Jain remains, certainly not Hindu ; and are from seven hundred years upwards old. Thus much I have deciphered from the pedestals of some statues scattered about.

There is in one of the largest pagodas an immense statue in bold relief of thirteen feet high, a single block of granite, with similar ones of eight feet two inches high on each side. All these smaller ones have inseriptions on their pedestals, said however by the Shastries I got from Kurgoond to be Muntrums, which they were very unwilling to read or repeat. One how- 
On apportioning the Supply of Oil, Ge. for Street-Lamps. 115

ever bears Sumvit 13; but this is beyond all probability without something else following. One pagoda (but which evidently differs from the rest) bears the name of Rajah Bular as the builder.

The town is entirely in ruins, and contains but seventy houses inhabited: these are in tolerable preservation. There are also eight large and four small pagodas, with vestiges of as many more.

The pagodas are of singular construction, of exquisite workmanship, and extreme superfluity of fine carving and ornaments of all kind. They are of hewn granite without cetnent, but clamped with iron every three or four inches. Some of the blocks supporting the upper parts of the doorways and entablatures are fourteen or fifteen feet long, and proportionably broad and thick.

They were intentionally thus much destroyed by the Mahomedans ; and most of the houses of the town are built with part of the materials.

The figures are ill-proportioned (in general), have curly hair, thick lips, very long ears, and are entirely naked, without string, bracelets, armlets, or any ornament, with the exception of one female figure with a species of sash. There are abundance of small figures in relief, in the entablatures, columns, \&c. well carved; and female figures also well executed, in general in graceful attitudes, support brackets, the capitals of the columns, and other parts of the building.

I have troubled you thus far in advance with a sketch of Wone. It is well worth looking at, though at first you experience a feeling of disappointment. It would require, however, many days to take good sketches and decipher the inscriptions, particularly the former, as both outside and inside there is scarcely an inch uncarved in aly of them. I could not therefore attempt it, believing you would not like so much of my time devoted to this pursuit whilst my duty required me elsewhere: I have got however one or two scratches, which will perbaps convey some notion of their style of building and figures. Yours, \&e.

(Signed) F. Dangerablo.

XVII. On apporlioning the Supply of Oil, Naphtha, or Gas, necessary for Street-Lamps, according to the varying $L$ engths of the Nights of the Year. By A ConRtispondext.

\section{To Mr. Tilloch.}

SIR, - $W_{E}$ happily live in an Age, when Science has assumed a more correct and practicable form, and its deductions become P 2 more 